DOI: https://doi.org/10.47405/mjssh.v6i2.659

\begin{tabular}{|c|c|}
\hline & Malaysian Journal of Social Sciences and Humanities (MJSSH) \\
\hline Malaysian Journal of & Volume 6, Issue 2, February 2021 \\
\hline 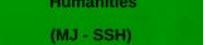 & e-ISSN : 2504-8562 \\
\hline & $\begin{array}{l}\text { Journal home page: } \\
\text { www.msocialsciences.com }\end{array}$ \\
\hline
\end{tabular}

\title{
Core Self-evaluations and Psychological Health among Nurses: The Mediating Role of Work-family Conflict
}

\author{
Suzana Mohd Hanifa' ${ }^{1}$, Zanariah Ismail1 \\ 1Department of Human Development and Family Studies, Faculty of Human Ecology, Universiti Putra Malaysia \\ (UPM)
}

Correspondence: Suzana Mohd Hanifa (suzanahaziq@gmail.com)

\begin{abstract}
Changes in the workforce demographics have led many individuals, particularly women, to experience work-family conflict as they juggle between their work and family roles. However, not much is known about the role of work-family conflict in the relationship between positive personality traits, namely, core self-evaluations and psychological health, among nurses. Thus, this study presents a model which examines the impact of core self-evaluations on nurses' psychological health (i.e., psychological distress and life satisfaction) and whether work-family conflict will have a mediating influence on such relationship. Based on the ecological systems theory and the conservation of resources theory, the model proposes that core self-evaluations will have a direct effect on work-family conflict, life satisfaction and psychological distress in nurses. In addition, it is hypothesised that core selfevaluations will have an indirect effect on life satisfaction and psychological distress through workfamily conflict. Finally, this model highlights the importance of core self-evaluations as personal resources that can protect nurses from work-family conflict and enhance their psychological health.
\end{abstract}

Keywords: core self-evaluations, work-family conflict, psychological distress, life satisfaction

\section{Introduction}

In the past few decades, work-family conflict has become a common phenomenon among working women due to the changing scenarios of workforce demographic, family characteristics, and the increasing usage of new technology in the work environment. The multitasking responsibilities performed in the two most important domains of a woman's life (i.e., work and family) have become sources of stress that impacts psychological health. The process of juggling between work and family responsibilities have exposed women to higher levels of stress, which may eventually lead to mental health problems if the burden becomes unbearable.

Moreover, women in the healthcare industry, especially nurses who work in the public hospitals, are at risk of experiencing work-family conflict and psychological health problems. This is because nursing is a profession that is largely dominated by women (Aiken et al., 2013). In addition, nursing is a highly demanding profession which exposes nurses to various job stressors, such as work overloads (McVicar, 2003), poor and stressful working conditions (Aiken et al., 2011), emotional demands, traumatic events (Adriaenssens et al., 2015), workplace aggression (Jaradat et al., 2016), and irregular work schedules (Matheson et al., 2014; Perrucci et al., 2007; Tahghighi et al., 2017). 
Most extant research on the contributing factors for nurses' experience of work-family conflict and psychological health in the Western (McVicar, 2003; Yildirim \& Aycan, 2008; Pisanti et al., 2011) and Malaysian contexts (Emilia \& Ismail, 2007; Fauziah et al., 2006; Nazatul et al., 2008; Raja Lexshimi et al., 2007; Sharifah et al., 2011) have tended to focus on certain aspects of job demands as the antecedents of these variables. Limited studies have considered personal resources, in particular, positive personality traits, as determinants of work-family conflict (Allen et al., 2012; Eby, Casper, Lockwood et al., 2005; Michel \& Clark, 2011) and psychological health (Judge et al., 2012). Thus, this study proposes a model to investigate the association of core self-evaluations and psychological health among nurses. The model also examines the mediating role of work-family conflict in the association between core self-evaluations and psychological health.

In the context of this study, psychological health was conceptualised as an integrative construct that covers both the positive and negative dimensions of mental states. This conceptualisation is consistent with other studies which noted that the assessment of psychological health should be measured based on the absence of negative symptoms as well as the presence of healthy psychological well-being (Bartlett \& Coles, 1998; Dagenais-desmarais et al., 2014; Massé et al., 1998; World Health Organization, 2004). Specifically, the proposed model measures psychological health using two indicators, namely, psychological distress and life satisfaction, which represents the negative mental states and positive signs of well-being, respectively.

\section{Theoretical Background}

\section{Ecological Systems Theory}

This theory postulates that development is based on the ongoing interactions between the individual and the environment (Brofenbrenner, 1979). Specifically, this theory conceptualises the environment in the context of four levels of ecological systems that are nested within one another: the microsystem, the mesosystem, the exosystem, and the macrosystem. The proposed model used this theory to examine the two main domains of a nurse's life (i.e., work and family) and how the interaction between them in the mesosystem impacts well-being.

\section{Conservation of Resources Theory}

The conservation of resources theory highlights the role of resources in explaining how an individual deals with stressful life events, such as, work-family conflict, that threatens well-being. This theory suggests that stress occurs if a person is exposed to threats involving losing resources, actually losing resources, or not being able to gain resources (Hobfoll, 1989). Specifically, this theory explains that individuals who have adequate resources are less vulnerable to stressful situations (Hobfoll, 1989). By employing this theory, the proposed model hypothesises that resource gain in the form of personal resources can offset the negative impact of resource loss for nurses when they are facing work-family conflict. Thus, nurses with more resources are expected to manage the demands of their work and family successfully, henceforth leading them to feel more satisfied with life and experience less distress.

\section{Literature Review}

\section{Core Self-Evaluations and Psychological Health}

Core self-evaluations are "the fundamental assessments that people make about their worthiness, competence, and capabilities" (Judge, Bono, Erez, \& Locke, 2005, p. 257). Core self-evaluations comprise four different specific traits, namely, emotional stability, self-esteem, locus of control, and generalised self-efficacy (Chang, Ferris, Johnson, Rosen, \& Tan, 2012; Judge et al., 2005). These four elements of traits focus on positive beliefs on one's own ability and self-worth that can influence behaviours. Presently, there are only a handful of empirical studies that have demonstrated the 
significant association between core self-evaluations and health and well-being. This is because most of the previous studies on core self-evaluations have concentrated on the organisational context (Tsaousis, Nikolaou, Serdaris, \& Judge, 2007), while less attention has been given to health and wellbeing (Judge at el., 2005).

Several studies have reported that core self-evaluations are negatively associated with psychological distress (Best, Stapleton \& Downey, 2005; Chang et al., 2012; McNall \& Michel, 2017; Tsaousis et al., 2007). In contrast, core self-evaluations have been found to be positively related to life satisfaction (Chang et al., 2012; Judge, Locke, Durham \& Kluger, 1998; Rey \& Extremera, 2014; Song, Kong \& Jin, 2013). Consistent with the conservation of resources theory, the findings of the previous literature emphasise the importance of core self-evaluations as personal resources in fostering healthy psychological well-being. Based on the review of empirical literature and the conservation of resources theory, the following hypotheses are proposed:

Hypothesis 1a: There is a significant negative association between core self-evaluations and psychological distress.

Hypothesis 1b: There is a significant positive association between core self-evaluations and life satisfaction.

\section{Core Self-Evaluations and Work-Family Conflict}

Work-family conflict is defined as "a form of inter-role conflict in which role pressures from the work and family domains are mutually incompatible in some respects" (Greenhaus \& Beutell, 1985, p.77). Specifically, it refers to the incompatibility between work and family roles. The literature has highlighted the importance of personality or dispositional variables as the main contributing factors for work-family conflict (Allen et al., 2012; Eby et al., 2005; Michel \& Clark, 2011). Although there are a handful of studies which reported that personal characteristics contribute to work-family conflict, they mainly focused on negative traits or personalities (Allen et al., 2012; Michel \& Clark, 2011). To date, only a few studies have focused on positive traits or personalities, particularly, core self-evaluations, and how they influence work-family conflict. For example, Boyar and Mosley (2007) found that core self-evaluations were negatively associated with work-family conflict among 124 employees at a retirement center or nursing home in the USA. In another study, Michel and Clark (2013) examined the association between core self-evaluations and work-family conflict among 380 employees in the USA. By utilising a direct approach to evaluate core self-evaluations, they found that core selfevaluation was a significant predictor of both directions of work-family conflict. Likewise, Haines, Harvey, Durand and Marchand (2013) investigated core self-evaluations, work-family conflict, and burnout among 289 police officers and civilian staff. Their results showed that core self-evaluations were negatively associated with both work-to-family conflict and family-to-work conflict. Based on these findings, the following hypothesis was formulated:

Hypothesis 2: There is a significant negative association between core self-evaluations and workfamily conflict.

\section{Work-Family Conflict and PsychologicalHealth}

In the work-family literature, work-family conflict is a major stressor that has a negative impact on individual well-being. Numerous studies have discussed the consequences of work-family conflict on both physical and psychological health. In the context of psychological health, most prior studies have conceptualised psychological health using multiple dimensions, including, work-related psychological health, family-related psychological health, and general psychological health (Allen, Herst, Bruck, \& Sutton, 2000; Amstad, Meier, Fasel, Elfering, \& Semmer, 2011; Greenhaus, Allen, \& Spector, 2006; Nohe, Meier, Sonntag, \& Michel, 2015).

In the context of the nursing profession, burnout has been extensively discussed in the work-family literature (Gisler et al., 2018), whereas limited studies have focused on domain-unspecific psychological health outcomes such as psychological distress and life satisfaction (Amstad et al., 
2011). Earlier studies have shown that work-family conflict has a negative relationship with psychological distress in the nursing population (Burke \& Greenglass, 1999; Hao, Wu, Liu, Li, \& Wu, 2015; Minnotte, Gravelle \& Minnotte, 2013; Zhang, Duffy, \& De Cattillero, 2017). In contrast, workfamily conflict has been found to be positively associated with life satisfaction among nurses (Yildrim and Aycan, 2008). In the Malaysian context, Rashid, Nordin, Omar, and Ismail (2013) examined 689 nurses in public hospitals in Malaysia and reported that work-family conflict was negatively associated with overall satisfaction. Similarly, Husin and Noor (2007) reported that work-family conflict was positively related to psychological strain among nurses in the government hospitals in the East Coast of Peninsular Malaysia. Based on the above literature review, it can be assumed that work-family conflict impacts nurses' psychological health, thus the following hypotheses are proposed:

Hypothesis 3a: There is a significant positive association between work-family conflict and psychological distress.

Hypothesis 3b: There is a significant negative association between work-family conflict and life satisfaction.

\section{Work-Family Conflict as a Mediator}

The literature has established the mediating impact of work-family conflict on the association between work-family factors and employee well-being. For instance, the integrative model of work-family interface developed by Frone, Russel, and Cooper (1992) is an established model that emphasises the role of work-family conflict as a mediator in the relationship between various types of work and family domain antecedents and a wide range of individual outcomes. Several other models have also proposed that work-family conflict is an important mediating variable between work-family conditions and individual outcomes (Carlson \& Perrewe, 1990; Michel, Mitchelson, Kotrba, LeBreton, \& Baltes, 2009). However, most studies in the work-family literature have focused on work-family conflict as a mediator between work-family demands and individual well-being (Eby et al., 2005; Winefield, Boyd, $\&$ Winefield, 2014). Thus, the proposed framework focuses on personal resources as the determinants of work-family conflict and how it can influence psychological health. Based on these findings, the following hypotheses are proposed:

Hypothesis 4a: Work-family conflict mediates the association between core self-evaluations and psychological distress.

Hypothesis 4b: Work-family conflict mediates the association between core self-evaluations and life satisfaction.

\section{The Proposed Model}

The proposed model was developed based on the ecological systems theory and the conservation of resources theory. The ecological systems theory posits that the interaction between the work and family domains impacts well-being (Brofenbrenner, 1979). Additionally, the conservation of resources theory suggests that resource gain, unlike resource loss, enhances individual well-being (Hobfoll, 1989), Thus, nurses with greater resources are less vulnerable to resource loss, and are therefore likely to experience greater well-being.

The proposed model also extends previous models by highlighting core self-evaluations as a contributing factor to work-family conflict and psychological health among nurses. In this context, core self-evaluations have been identified as a useful personal resource that may protect nurses from stressful situations due to work-family conflict, thus enhance their psychological health. In addition, the proposed model also examines work-family conflict as an important mediating variable in the relationship between core self-evaluations and nurses' psychological health. The proposed model of the study is depicted in Figure 1: 
Figure 1: Proposed Model

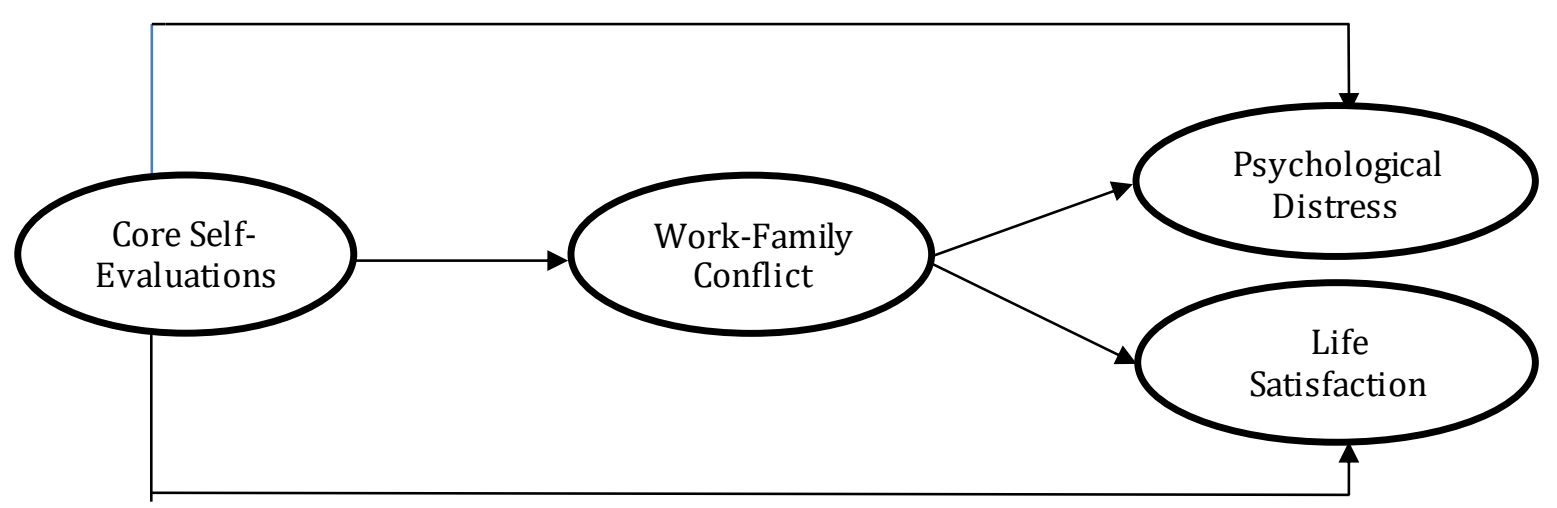

\section{Conclusion}

This model proposes that core self-evaluations have a direct effect on nurses' experience of workfamily conflict and psychological health (i.e., psychological distress and life satisfaction). Additionally, core self-evaluations are also hypothesised to have an indirect effect on psychological health through work-family conflict. The model implies that there is a need to realize the importance of positive personal characteristics on nurses' psychological health. Finally, this research may improve our understanding of psychological health as a multi-dimensional construct by examining psychological distress and life satisfaction as separate dimensions in a single research. By doing this, the present study provides insights into how personal resources, that is, core self-evaluations, can contribute to nurses' psychological distress and life satisfaction differently.

\section{References}

Adriaenssens, J., De Gucht, V., \& Maes, S. (2015). Determinants and prevalence of burnout in emergency nurses: A systematic review of 25 years of research. International Journal of Nursing Studies, 52(2), 649-661. doi:10.1016/j.jinurstu.2014.11.004.

Aiken, L. H., Sloane, D. M., Bruyneel, L., Van den Heede, K., \& Sermeus, W. (2013). Nurses' reports of working conditions and hospital quality of care in 12 countries in Europe. International Journal of Nursing Studies, 50(2), 143-153. doi:10.1016/j.ijnurstu.2012.11.009.

Aiken, L. H., Sloane, D. M., Clarke, S. P., Poghosyan, L., Cho, E., You, L., ... Aungsuroch, Y. (2011). Importance of work environments on hospital outcomes in nine countries. International Journal for Quality in Health Care, 23(4), 357-364. doi:10.1093/intqhc/mzr022.

Allen, T. D., Herst, D. E. L., Bruck, C. S., \& Sutton, M. (2000). Consequences associated with workto-family conflict: A review and agenda for future research. Journal of Occupational Health Psychology, 5(2), 278-308. doi:10.1037//1076-899B.5.2.278.

Allen, T. D., Johnson, R. C., Saboe, K. N., Cho, E., Dumani, S., \& Evans, S. (2012). Dispositional variables and work-family conflict: A meta-analysis. Journal of Vocational Behaviour, 80, 17 26. doi:10.1016/j.jvb.2011.04.004.

Amstad, F. T., Meier, L. L., Fasel, U., Elfering, A., \& Semmer, N. K. (2011). A meta-analysis of work-family conflict and various outcomes with a special emphasis on cross-domain versus matching-domain relations. Journal of Occupational Health Psychology, 16(2), 151-69. doi:10.1037/a0022170.

Bartlett, C. J., \& Coles, E. C. (1998). Psychological health and well-being: Why and how should public health specialists measure it? Part 2: Stress, subjective well-being and overall conclusions. Journal of Public Health, 20(3), 288-294. doi:10.1093/oxfordjournals.pubmed.a024771. 
Best, R. G., Stapleton, L. M., \& Downey, R. G. (2005). Core self-evaluations and job burnout: The test of alternative models. Journal of Occupational Health Psychology, 10(4), 441-451. doi:10.1037/1076-8998.10.4.441.

Boyar, S. L., \& Mosley, D. C. (2007). The relationship between core self-evaluations and work and family satisfaction: The mediating role of work-family conflict and facilitation. Journal of Vocational Behaviour, 71(2), 265-281. doi:10.1016/j.jvb.2007.06.001.

Bronfenbrenner, U. (1979). The ecology of human development: Experiments by nature and design. Cambridge, MA: Harvard University Press.

Burke, R. J., \& Greenglass, E. R. (1999). Work-family conflict, spouse support, and nursing staff wellbeing during organisational restructuring. Journal of Occupational Health Psychology, 4(4), 327-336. doi:10.1037/1076-8998.4.4.327.

Carlson, D. S., \& Perrewe, P. L. (1999). The role of social support in the stressor-strain relationship: An examination of work-family conflict. Journal of Management, 25(4), 513-540. doi:10.1177/014920639902500403.

Chang, C. H. (Daisy), Ferris, D. L., Johnson, R. E., Rosen, C. C., \& Tan, J. A. (2012). Core selfevaluations: A review and evaluation of the literature. Journal of Management, 38(1), 81-128. doi:10.1177/0149206311419661.

Dagenais-desmarais, V., Forest, J., Girouard, S., \& Crevier-Braud, L. (2014). The importance of needsupportive relationships for motivation and psychological health at work. In N. Weinstein (Ed.), Human Motivation and Interpersonal Relationships: Theory, Research, and Applications, 263297, Springer Science+Business Media Dordrecht. doi:10.1007/978-94-017-8542-6.

Eby, L T., Casper, W. J., Lockwood, A., Bordeaux, C., \& Brinley, A. (2005). Work and family research in IO/OB: Content analysis and review of the literature (1980-2002). Journal of Vocational Behaviour, 66(1), 124-197. doi:10.1016/j.jvb.2003.11.003.

Emilia, Z. A., \& Ismail, N. H. (2007). Work-related stress and coping: A survey on medical and surgical nurses in a Malaysian teaching hospital. Jurnal Kesihatan Masyarakat, 13(1), 55-66. Retrieved from http://journalarticle.ukm.my/4595/1/Vol13(1)-khalib.pdf.

Fauziah, N., Quek., K. F., \& Agus Salim, M. B. (2006). Relationship between nature of work and psychosocial among nurses working in Hospital Selayang, Selangor. Malaysian Journal of Public Health Medicine, 6(2), 56-61.

Frone, M. R., Russell, M., \& Cooper, M. L. (1992). Antecedents and outcomes of work-family conflict: Testing a model of the work-family interface. Journal of Applied Psychology, 77(1), 65-78. doi:10.1037/0021-9010.77.1.65.

Gisler, S., Omansky, R., Alenick, P. R., Tumminia, A. M., Eatough, E. M., \& Johnson, R. C. (2018). Work-life conflict and employee health: A review. Journal of Applied Biobehavioural Research, 23(4), 1-46. doi:10.1111/jabr.12157.

Greenhaus, J. H., Allen, T. D., \& Spector, P. E. (2006). Health consequences of work-family conflict: The dark side of the work-family interface. In P. L. Perrewé \& D. C. Ganster (Eds.), Research in occupational stress and well-being Vol. 5: Employee Health, Coping and Methodologies, (pp.61-98). Elsevier Ltd. doi:10.1016/S 1479-3555(05)05002-X.

Greenhaus, J. H., \& Beutell, N. J. (1985). Sources of conflict between work and family roles. Academy of Management Review, 10(1), 76-88. doi:10.5465/AMR.1985.4277352.

Haines, V. Y., Harvey, S., Durand, P., \& Marchand, A. (2013). Core self-evaluations, work-family conflict, and burnout. Journal of Marriage and Family, 75(3), 778-793. doi:10.1111/jomf.12026.

Hao, J., Wu, D., Liu, L., Li, X., \& Wu, H. (2015). Association between work-family conflict and depressive symptoms among Chinese female nurses: The mediating and moderating role of psychological capital. International Journal of Environmental Research and Public Health, 12(6), 6682-6699. doi:10.3390/ijerph120606682.

Hobfoll, S. E. (1989). Conservation of resources. A new attempt at conceptualizing stress. American Psychologist, 44(3), 513-524. doi:10.1037/0003-066X.44.3.513.

Husin, R., \& Noor, N. M. (2007). Work-family conflict, coping and well-being in nurses. In The Third International Research Colloquium: Research In Malaysia and Thailand (pp. 131-163). International Islamic University Malaysia.

Jaradat, Y., Nielsen, M. B., Kristensen, P., Nijem, K., Bjertness, E., Stigum, H., \& Bast-Pettersen, R. (2016). Workplace aggression, psychological distress, and job satisfaction among Palestinian 
DOI: https://doi.org/10.47405/mjssh.v6i2.659

nurses: A cross-sectional study. Applied Nursing Research, 32, 190-198. doi.org/10.1016/j.apnr.2016.07.014

Judge, T. A., Bono, J. E., Erez, A., \& Locke, E. A. (2005). Core self-evaluations and job and life satisfaction: The role of self-concordance and goal attainment. Journal of Applied Psychology, 90(2), 257-268. doi:10.1037/0021-9010.90.2.257.

Judge, T. A., Ilies, R., \& Zhang, Z (2012). Genetic influences on core self-evaluations, job satisfaction, and work stress: A behavioural genetics mediated model. Organisational Behaviour and Human Decision Processes, 117(1), 208-220. doi:10.1016/j.obhdp.2011.08.005.

Judge, T. A., Locke, E. A., Durham, C. C., \& Kluger, A. N. (1998). Dispositional effects on job and life satisfaction: The role of core evaluations. Journal of Applied Psychology, 83(1), 17-34. doi:10.1016/j.sbspro.2015.04.917.

Massé, R., Poulin, C., Dassa, C., Lambert, J., Bélair, S., \& Battaglini, A. (1998). The structure of mental health: Higher-order confirmatory factor analyses of psychological distress and wellbeing measures. Social Indicators Research, 45(1-3), 475-504. doi:10.1023/A:1006992032387.

Matheson, A., O'Brien, L., \& Reid, J. A. (2014). The impact of shiftwork on health: A literature review. Journal of Clinical Nursing, 23(23-24), 3309-3320. doi.org/10.1111/jocn.12524.

McNall, L. A., \& Michel, J. S. (2017). The relationship between student core self-evaluations, support for school, and the work-school interface. Community, Work and Family, 20(3), 253-272. doi:10.1080/13668803.2016.1249827.

McVicar, A. (2003). Workplace stress in nursing: A literature review. Journal of Advanced Nursing, 44(6), 633-642. doi:10.1046/j.0309-2402.2003.02853.x.

Michel, J. S., \& Clark, M. A. (2013). Investigating the relative importance of individual differences on the work-family interface and the moderating role of boundary preference for segmentation. Stress and Health, 29(4), 324-336. doi:10.1002/smi.2474.

Michel, J.S., \& Clark, M.A. (2011). Personality and work-life integration. In S. Kaiser, M. J. Ringlstetter, D. R. Eikhof, \& M. P. Cunha,. (Eds.), Creating Balance? International Perspectives on the Work-Life Integration of Professional. (pp 81-99). Springer-Verlag Berlin Heidelberg. doi.org/10.1007/978-3-642-16199-5_5.

Michel, J. S., Mitchelson, J. K., Kotrba, L. M., LeBreton, J. M., \& Baltes, B. B. (2009). A comparative test of work-family conflict models and critical examination of work-family linkages. Journal of Vocational Behaviour, 74(2), 199-218. doi:10.1016/j.jvb.2008.12.005.

Minnotte, K. L., Gravelle, M. \& Minnotte, M. C. (2013). Workplace characteristics, work-to-life conflict, and psychological distress among medical workers. The Social Science Journal, 50(4), 408-417. doi:10.1016/j.soscij.2013.08.001.

Nazatul, S. M., Saimy, I., Moy, F. M., \& Nabila, A. S. (2008). Prevalence of sleep disturbance among nurses in a Malaysian government hospital and its association with work characteristics. Journal of Health and Translational Medicine, 11(2), 66-71.

Nohe, C., Meier, L. L., Sonntag, K., \& Michel, A. (2015). The chicken or the egg? A meta-analysis of panel studies of the relationship between work-family conflict and strain. Journal of Applied Psychology, 100(2), 522-536. doi:10.1037/a0038012.

Perrucci, R., MacDermid, S., King, E., Tang, C.-Y., Brimeyer, T., Ramadoss, K., .. Swanberg, J. (2007). The significance of shift work: Current status and future directions. Journal of Family and Economic Issues, 28(4), 600-617. doi:10.1007/s10834-007-9078-3.

Pisanti, R., van der Doef, M., Maes, S., Lazzari, D., \& Bertini, M. (2011). Job characteristics, organisational conditions, and distress/well-being among Italian and Dutch nurses: A crossnational comparison. International Journal of Nursing Studies, 48(7), 829-837. doi:/10.1016/j.ijnurstu.2010.12.006.

Raja Lexshimi, R., Tahir, S., Santhna, L. P., \& Md Nizam, J. (2007). Prevalence of stress and coping mechanism among staff nurses in the intensive care unit. Med \& Health, 2(2), 146-153.

Rashid W. E. W., Nordin, M. S., Omar, A., \& Ismail, I. (2013). Work/Family conflict: The link between self-Esteem and satisfaction outcomes. Procedia - Social and Behavioral Sciences, 65(ICIBSoS), 564-569. doi.org/10.1016/j.sbspro.2012.11.166

Rey, L., \& Extremera, N. (2014). Core self-evaluations, perceived stress and life satisfaction in Spanish young and middle-aged adults: An examination of mediation and moderation effects. Social Indicators Research, 120, 515-524. doi:10.1007/s11205-014-0601-2. 
DOI: https://doi.org/10.47405/mjssh.v6i2.659

Sharifah Zainiyah, S. Y., Afiq, I. M., Chow, C. Y., \& Siti Sara, D. (2011). Stress and its associated factors amongst ward nurses in a public Hospital Kuala Lumpur. Malaysian Journal of Public Health Medicine, 11(1), 78-85.

Song, G., Kong, F., \& Jin, W. (2013). Mediating effects of core self-evaluations on the relationship between social support and life satisfaction. Social Indicators Research, 114(3), 1161-1169. doi:10.1007/s11205-012-0195-5.

Tahghighi, M., Rees, C. S., Brown, J. A., Breen, L. J., \& Hegney, D. (2017). What is the impact of shift work on the psychological functioning and resilience of nurses? An integrative review. Journal of Advanced Nursing. doi:10.1111/jan.13283.

Tsaousis, I., Nikolaou, I., Serdaris, N., \& Judge, T. A. (2007). Do the core self-evaluations moderate the relationship between subjective well-being and physical and psychological health? Personality and Individual Differences, 42(8), 1441-1452. doi:0.1016/j.paid.2006.10.025.

Winefield, H. R., Boyd, C., \& Winefield, A. H. (2014). Work-family conflict and well-being in university employees. The Journal of Psychology: Interdisciplinary and Applied, 148(6), 683697. doi:10.1080/00223980.2013.822343.

World Health Organisation (WHO). (2004). Promoting mental health: concepts, emerging evidence, practice (Summary Report). World Health Organisation. Geneva, Switzerland.

Yildirim, D., \& Aycan, Z. (2008). Nurses' work demands and work-family conflict: A questionnaire survey. International Journal of Nursing Studies, 45(9), 1366-1378. doi:10.1016/j.ijnurstu.2007.10.010.

Zhang, Y., Duffy, F. J., \& de Cattillero, R. E. (2017). Do sleep disturbances mediate the association between work- family conflict and depressive symptoms among nurses? A cross-sectional study. Journal of Psychiatric and Mental Health, 24(8), 620-628. doi:10.1111/jpm.12409. 